\title{
PENGARUH MEDIA PEMBELAJARAN DAN KETERAMPILAN PENGELOLAAN KELAS TERHADAP PRESTASI BELAJAR SISWA SMK NEGERI 5 MADIUN
}

\author{
Dian Arumsari \\ Pendidikan Akuntansi FKIP Universitas PGRI Madiun \\ arumsaridian52@gmail.com
}

\begin{abstract}
ABSTRAK
Penelitian ini bertujuan untuk menguji pengaruh media pembelajaran dan keterampilan pengelolaan kelas terhadap prestasi belajar siswa kelas X pada mata pelajaran Akuntansi di SMK Negeri 5 Madiun tahun pelajaran 2015/2016. Populasi dalam penelitian ini adalah 108 siswa kelas X Ak SMK Negeri 5 Madiun. Penulis menggunakan teknik proporsional sampling dan jumlah sampel yang diambil dalam penelitian ini adalah 84 siswa yang diambil secara acak dari 3 kelas dengan proporsi masing-masing kelas diwakili oleh 28 siswa. Data dalam penelitian ini adalah data primer yaitu kuesioner dan data sekunder yaitu nilai siswa selama mengikuti pembelajaran. Metode analisis data menggunakan multiple regression. Hasil analisis menunjukkan bahwa media pembelajaran dan keterampilan pengelolaan kelas secara signifikan berpengaruh positif terhadap prestasi belajar siswa. Keterampilan pengelolaan kelas memiliki pengaruh paling dominan terhadap prestasi belajar siswa
\end{abstract}

Kata Kunci : Media pembelajaran; Keterampilan pengelolaan kelas; Prestasi belajar

\begin{abstract}
This study aim is to examine the influence of instructional media and skills of classroom management on student achievement of class X on the subjects of Accounting at SMK Negeri 5 Madiun academic year 2015/2016. The population in this study were 108 students of class X Ak SMK Negeri 5 Madiun. The authors used proportional sampling technique and the number of samples taken in this study were 84 students taken randomly from 3 classes with the proportion of each class represented by 28 students. Data in this research is primary data that is questionaire and secondary data is the student mark during the class. Methods of data analysis using multiple regression. The analysis showed that the media learning and classroom management skills significantly positive effect on student achievement. Classroom management skills have the most dominant influence on student achievement.
\end{abstract}

Keywords: Learning media; Classroom management skills;

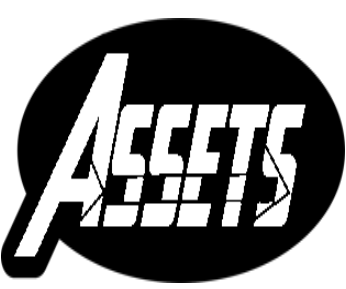

ASSETS:

Jurnal Akuntansi dan Pendidikan Vol. 6 No. 1

Hlmn. 13-25

Madiun, April 2017 p-ISSN: 2302-6251 e-ISSN: 2477-4995

Artikel masuk: 4 Januari 2017

Tanggal diterima: 24 Januari 2017 


\section{ASSEES JURNAL AKUNTANSI DAN PENDIDIKAN

\section{PENDAHULUAN}

Pendidikan merupakan salah satu upaya mendidik generasi penerus bangsa agar memiliki pengetahuan yang tinggi dan keterampilan untuk membekali hidupnya di masyarakat. Dunia pendidikan dituntut untuk mempunyai output yang berkompetensi tinggi dengan meningkatkan proses kegiatan belajar mengajar di sekolah khususnya di kelas. Pendidikan mempunyai peranan yang sangat penting untuk meningkatkan kualitas generasi muda, sehingga proses pendidikan harus diperhatikan agar hasil yang diinginkan dapat tercapai. Proses pendidikan yang baik dapat menghasilkan suatu pekerja atau sumber daya manusia yang benar-benar ahli dan memiliki keterampilan yang optimal pada bidangnya. Sumber daya yang berpotensi diharapkan dapat mengimbangi laju perkembangan dan kemajuan ilmu pengetahuan dan teknologi.

Prestasi belajar merupakan suatu hasil yang dicapai seseorang setelah menyelesaikan pekerjaan, tugas rumah, ulangan formatif, perlombaan maupun hasil yang dicapai dari kegiatan lain baik di sekolah maupun di luar sekolah. Menurut Tu'u (2004: 75), prestasi belajar adalah hasil belajar yang dicapai siswa ketika mengikuti dan mengerjakan tugas dan kegiatan pembelajaran di sekolah.Prestasi belajar adalah hasil yang diperoleh berupa kesan-kesan yang mengakibatkan perubahan dalam diri individu sebagai hasil dari aktivitas dalam belajar (Djamarah, 2002: 88). Prestasi belajar adalah hasil yang diperoleh siswa dari kegiatan yang telah dilakukannya seperti ujian sekolah, ulang harian maupun partisipasinya dalam mengikuti perlombaan. Prestasi belajar siswa tersebut dinilai dari beberapa aspek dan kriteria penilaian tertentu, misalnya dari aspek kognitif, aspek afektif maupun dari aspek psikomotornya yangditunjukkan dengan nilai atau angka sebagai hasil dari evaluasi yang dilakukan oleh guru maupun penguji.

Salah satu upaya untuk meningkatkan proses kegiatan belajar mengajar adalah penggunaan media pembelajaran. Media pembelajaran atau bisa disebut media pendidikan adalah suatu alat maupun sarana baik media visual atau audiovisual yang dapat digunakan untuk membantu siswa dalam menyerap materi dan dapat meningkatkan motivasi belajar siswa. Media pendidikan merupakan suatu alat atau perantara yang berguna untuk memudahkan proses belajar mengajar, dalam rangka mengefektifkan komunikasi antara guru dan murid (Syukur, 2008:117). Sedangkan menurut Djamarah dan Zain (2002: 137), media adalah alat bantu apa saja yang dapat dijadikan sebagai penyalur pesan guna mencapai tujuan pengajaran.Jadi, media pembelajaran adalah suatu alat bantu yang digunakan oleh guru dalam mendukung proses pembelajaran dan dapat membantu siswa dalam menerima materi. Media pembelajaran merupakan perantara komunikasi antara guru dan siswa dan dapat memudahkan interaksi antara keduanya.

Penggunaan media pembelajaran seperti yang disebutkan di atas, ditujukan untuk meningkatkan efektifitas dan efisiensi proses belajar mengajar sehingga diharapkan anak-anak mampu mengembangkan daya nalar serta daya rekanya dan berdampak pada peningkatan prestasi belajarnya.Proses belajar mengajar dengan menggunakan sarana audio visual mampu meningkatkan efisiensi pengajaran 20\%50\% (Darwanto: 101).Penggunaan media pengajaran dapat mempertinggi proses dan hasil belajar yang berkenaan dengan taraf pikir siswa, berpikir siswa dimulai dari yang kongkret menuju yang abstrak, dari yang sederhana menuju yang abstrak, dari yang sederhana menuju yang komplek (Syukur, 2008: 120). Dari beberapa pendapat di atas dapat disimpulkan bahwa penggunaan media pembelajaran dalam proses belajar mengajar dapat berpengaruh terhadap prestasi belajar siswa. Apabila media yang digunakan sesuai dengan materi pelajaran dan mempengaruhi motivasi siswa, maka 
dapat meningkatkan prestasi belajar siswa. Maka, peneliti mengajukan dugaan sementara pertama, yaitu media pembelajaran berpengaruh positif terhadap prestasi belajar.

Selain itu keterampilan guru dalam menciptakan pengelolaan kelas yang efektif dapat menunjang proses belajar mengajar di kelas.Guru tidak hanya berperan sebagai pendidik, pembimbing, motivator, mediator dan fasilitator saja, namun juga harus berperan sebagai pengelola kelas. Efektif tidaknya pembelajaran di kelas tergantung dari bagaimana cara guru dalam mengelola suatu kelas dan mengkondisikan kelas tersebut. Kelas yang dikelola dengan baik akan menunjang jalannya interaksi edukatif, sebaliknya kelas yang tidak dikelola dengan baik akan menghambat kegiatan pembelajaran (Djamarah, 2000:47).

Berdasarkan beberapa pengertian di atas, penulis dapat menyimpulkan pengertian pengelolaan kelas adalah suatu kegiatan pengaturan kelas dalam upaya menciptakan dan mengkondisikan suasana kelas dengan sebaik-baiknya agar siswa merasa betah berada di dalam kelas dan siap untuk mengikuti proses belajar mengajar. Setiap guru harus memahami makna pengelolaan kelas, karena cara guru untuk mengelola suatu kelas juga berpengaruh terhadap prestasi belajar siswa. Sedangkan yang dimaksud dengan keterampilan pengelolaan kelas adalah suatu kecakapan yang dimiliki seorang guru dalam mengatur, mengelola dan meciptakan kondisi belajar yang optimal agar tercipta suasana kelas yang kondusif dan mendukung demi terciptanya keberhasilan proses belajar mengajar.

Sebagai pengelola kelas guru bertanggung jawab memelihara lingkungan kelasnya agar tercipta suasana kelas yang kondusif dan membimbing proses-proses intelektual dan sosial di dalam kelas. Pengelolaan kelas bukanlah tugas yang ringan bagi seorang guru. Seorang guru harus memahami kondisi kelas yang sedang terjadi dan harus mengetahui karakter masing-masing siswa. Jika guru tidak dapat memahami hal tersebut, maka guru akan salah dalam melakukan pengelolaan kelas sehingga tujuan pembelajaran tidak akan tercapai. Sebaiknya guru juga memahami tentang teori belajar mengajar dan teori perkembangan peserta didik sehingga dapat memudahkan dalam menciptakan situasi belajar yang disukai siswa dan dapat mempermudah dalam pencapain tujuan pembelajaran. Selain itu, guru harus memahami prinsip-prinsip pengelolaan kelas untuk memudahkan guru dalam memecahkan masalah-masalah yang terjadi di dalam kelas dan dapat menciptakan pengelolaan kelas yang efektif. Prinsip-prinsip pengelolaan kelas meliputi hangat dan antusias, tantangan, bervariasi, keluwesan, penekanan pada hal-hal yang positif dan penanaman disiplin diri (Suyatno, 2008:64).

Keterampilan pengelolaan kelas merupakan suatu usaha yang sengaja dilakukan untuk mencapai tujuan pengajaran. Pengelolaan kelas merupakan keterampilan guru untuk menciptakan iklim pembelajaran yang kondusif, dan mengendalikannya jika terjadi gangguan dalam pembelajaran (Mulyasa, 2005:91). Menurut Sudirman dalam Djamarah(2006: 178), secara umum tujuan pengelolaan kelas adalah penyediaan fasilitas bagi bermacam-macam kegiatan belajar siswa dalam lingkungan sosial, emosional, dan intelektual dalam kelas, fasilitas yang disediakan itu memungkinkan siswa belajar dan bekerja, terciptanya suasana sosial yang memberikan kepuasan, suasana disiplin, perkembangan intelektual, emosional dan sikap serta apresiasi pada siswa.

Pengelolaan kelas adalah keterampilan guru untuk menciptakan dan memelihara kondisi belajar yang optimal dan mengembalikannya bila terjadi gangguan dalam proses belajar-mengajar (Usman, 2010: 97). Pengelolaan kelas dimaksudkan untuk menciptakan lingkungan belajar yang kondusif bagi anak didik sehingga tercapai 
tujuan pengajaran secara efektif dan efisien (Djamarah, 2006:174). Berdasarkan beberapa pendapat di atas, penulis dapat menyimpulkan bahwa keterampilan pengelolaan kelas yang dilakukan oleh guru dapat mempengaruhi prestasi belajar siswa. Hal ini merupakan tugas seorang guru dalam mengelola kelas agar kelas dapat terorganisasi dengan baik, pembelajaran dapat berjalan secara efektif sehingga dapat meningkatkan prestasi belajar siswa. Dugaan sementara kedua yang diajukan peneliti adalah keterampilan pengelolaan kelas berpengaruh positif terhadap prestasi belajar siswa. Peneliti menduga media pembelajaran dan keterampilan pengelolaan kelas berpengaruh positif secara simultan terhadap prestasi belajar siswa.

Dari hasil observasi yang dilakukan di SMK Negeri 5 Madiun di kelas X Ak, frekuensi penggunaan media pembelajaran pada saat pembelajaran akuntansi masih rendah tidak digunakan setiap pertemuan. Pembelajaran yang dilakukan kurang bervariasi. Akibatnya, siswa menjadi tidak tertarik dan tidak termotivasi dalam mengikuti proses belajar mengajar. Pengelolaan kelas yang efektif dan didukung penggunaan media pembelajaran sebagai alat dan sarana penunjang proses belajar mengajar seharusnya dapat dijadikan sebagai faktor yang dapat meningkatkan prestasi belajar siswa.Berdasarkan uraian latar belakang masalah tersebut maka peneliti tertarik untuk melakukan penelitian tentang pengaruh media pembelajaran dan keterampilan pengelolaan kelas terhadap prestasi belajar siswa kelas $\mathrm{x}$ pada mata pelajaran akuntansi di smk negeri 5 madiun tahun pelajaran 2015/2016.

\section{METODE PENELITIAN}

Populasi dalam penelitian ini adalah siswa kelas X Ak SMK Negeri 5 Madiun. Rincian data siswa terdapat pada Tabel 1. Peneliti menggunakan teknik proporsional sampling.Jumlah sampel yang diambil dalam penelitian ini adalah 84 siswa yang diambil secara acak dari 3 kelas dengan proporsi masing-masing kelas diwakili oleh 28 siswa.Dalam penelitian ini peneliti menggunakan data primer yaitu kuesioner dan data sekunder yaitu nilai siswa selama mengikuti pembelajaran.

Tabel 1. Data Siswa SMK Negeri 5 Madiun

\begin{tabular}{lc}
\hline \multicolumn{1}{c}{ Kelas } & Jumlah Siswa \\
\hline X Ak 1 & 36 \\
X Ak 2 & 36 \\
X Ak 3 & 36 \\
\hline Jumlah & 108 \\
\hline Sumber: SMKN 5 Madiun
\end{tabular}

Uji statistik yang digunakan meliputi uji validitas dan realibilitas instrumen. Instrumen yang valid berarti instrumen tersebut dapat digunakan untuk mengukur apa yang seharusnya diukur (Sugiyono, 2009:121). Instrumen yang valid dapat mengukur sesuatu dengan hasil sama walau dilakukan berkali-kali dan dimana-mana (Bungin, 2009: 121). Teknik yang digunakan untuk mengetahui validitas soal dapat dihitung dengan rumus Product Moment Person (dengan angka kasar).

Reliabilitas menunjukkan bahwa suatu instrumen cukup dapat dipercaya untuk digunakan sebagai alat pengumpul data karena instrumen tersebut sudah baik (Suharsimi, 2002:154).Rumus yang digunakan untuk mengetahui reliabilitas suatu instrumen adalah menggunakan rumus Alpha Cronbach.

Uji asumsi klasik yang digunakan dalam penelitian ini adalah multikolinieritas, heteroskedastisitas, dan normalitas.Tujuan dari uji asumsi ini adalah untuk menguji apakah pada model regresi ditemukan adanya korelasi antar variabel independen.Jika 
terjadi korelasi, maka dinamakan terdapat problem multikolinieritas (multiko).Rumus yang digunakan untuk menguji kemungkinan adanya multikolinieritas adalah dengan uji VIF.

Tujuan uji asumsi heteroskedastisitas adalah untuk menguji apakah dalam sebuah model regresi terjadi ketidaksamaan varians dari residual dari satu pengamatan ke pengamatan yang lain (Santoso, 2000: 208).Scatterplot dilakukan untuk menguji kemungkinan adanya heteroskedastisitas.

Uji asumsi klasik normalitas bertujuan untuk menguji apakah dalam sebuah model regresi, variabel dependen, variabel independen atau keduanya mempunyai distribusi normal ataukah tidak.Rumus yang digunakan untuk menguji adalah rasio Skewness dan rasio Kurtosis.

Regresi linear ganda digunakan untuk menganalisis ini bertujuan untuk mengetahui pengaruh sebab akibat dengan menentukan $Y$ (variabel terikat) dan untuk mengetahui nilai-nilai yang berhubungan dengan variabel $X$ (variabel bebas) dengan menggunakan rumus statistik. Rumus regresi ganda menurut Sugiyono (2009: 192) sebagai berikut:

Keterangan :

$$
Y=a+b_{1} X_{1}+b_{2} X_{2}
$$

Y : Prestasi belajar

$\mathrm{X}_{1} \quad$ : Media pembelajaran

$\mathrm{X}_{2} \quad$ : Keterampilan pengelolaan kelas

a :Konstanta

$\mathrm{b}_{1} \quad$ : Koefisien regresi $\mathrm{X}_{1}$

$b_{2} \quad:$ Koefisien regresi $X_{2}$

Uji hipotesis yang digunakan dalam penelitian ini adalah uji $t$ dan uji F.Uji $t$ digunakan untuk menguji signifikansi pengaruh masing-masing variabel independen terhadap variabel dependen. Apabilat hitung lebih kecil daripada $t_{\text {tabel }}$ maka keputusan menerima hipotesis nol (Ho). Artinya variabel independen $(X)$ tersebut tidak berpengaruh terhadap variabel dependen $(\mathrm{Y})$.

Uji F merupakan pengujian yang dilakukan untuk mengetahui apakah semua variabel independen mempunyai pengaruh yang sama terhadap variabel dependen. Pengujian dapat dilakukan dengan cara membandingkan antara nilai kritis $\mathrm{F}\left(\mathrm{F}_{\text {tabel }}\right)$ dengan nilai $\mathrm{F}_{\text {hitung }}$ (F-Ratio) yang terdapat pada tabel analisys of variance dari hasil perhitungan. Adapun hasilnya apabila $F_{\text {hitung }}$ lebih kecil daripada $F_{\text {tabel }}$ maka keputusannya menerima hipotesis nol (Ho).Artinya bahwa semua variabel independen $(X)$ tidak berpengaruh terhadap perubahan nilai variabel dependen $(Y)$.

\section{HASIL PENELITIAN DAN PEMBAHASAN}

Peneliti melakukan uji validitas terhadap item kuesioner. Jumlah item kuesioner media pembelajaran keseluruhan yang dinyatakan valid sejumlah 10 pertanyaan yang dikategorikan sebagai berikut (a) jumlah jawaban tertinggi $50(10 \times 5)$, (b) jumlah jawaban terendah $10(10 \times 1)$. Berdasarkan hasil olah data, 84 responden media pembelajaran yang mendukung belajar siswa sebagai berikut. Responden dengan kriteria tinggi sebanyak 47 responden yang memiliki interval nilai 38-50 dengan persentase sebesar $55,95 \%$, sedang sebanyak 36 responden yang memilki interval nilai 24-37 dengan persentase sebesar 42,86\% dan rendah sebanyak 1 responden yang memiliki interval nilai 10-23 dengan persentase sebesar 1,19\%. Deskripsi data terdapat pada Tabel 2. 
Tabel 2. Deskripsi Data Responden Media Pembelajaran

\begin{tabular}{cccc}
\hline Interval Nilai & Kriteria & Jumlah Responden & Persentase \\
\hline $50-38$ & Tinggi & 47 & $55,95 \%$ \\
$37-24$ & Sedang & 36 & $42,86 \%$ \\
$23-10$ & Rendah & 1 & $1,19 \%$ \\
\hline Total & & 84 & $100 \%$ \\
\hline
\end{tabular}

Jumlah item kuesioner keterampilan pengelolaan kelas keseluruhan yang dinyatakan valid sejumlah 12 pertanyaan yang dikategorikan: (a) jumlah jawaban tertinggi sebesar 60 (12 x 5), (b) jumlah jawaban terendah sebesar 12 (12x1). Berdasarkan olah data, kriteria keterampilan pengelolaan kelas dari 84 responden adalah sebagai berikut. Kriteria tinggi sebanyak 29 responden yang memiliki interval nilai 4560 dengan persentase sebesar $34 \%$, sedang sebanyak 40 responden yang memiliki interval nilai 29-44 dengan persentase sebesar $48 \%$ dan rendah sebanyak 15 responden yang memiliki interval nilai 12-28 dengan persentase sebesar $18 \%$ dinyatakan dengan kriteria rendah.

Tabel 3. Deskripsi Data Responden Keterampilan Pengelolaan Kelas

\begin{tabular}{cccc}
\hline Interval Nilai & Kriteria & Jumlah Responden & Persentase \\
\hline $60-45$ & Tinggi & 29 & $34 \%$ \\
$44-29$ & Sedang & 40 & $48 \%$ \\
$28-12$ & Rendah & 15 & $18 \%$ \\
\hline Total & & 84 & $100 \%$ \\
\hline
\end{tabular}

Hasil prestasi belajar siswa yang diperoleh dari sekolah dengan Kriteria Ketuntasan Minimal (KKM) 7,00 dapat dilihat pada Tabel 4. Deskripsi data tentang kriteria prestasi belajar siswa menunjukkan bahwa responden yang berada pada kriteria tinggi ada 14 responden (17\%), yaitu siswa yang memiliki interval nilai 83-100. Sedangkan, 70 responden yang memiliki interval nilai 65 - 82 dengan persentase sebesar $83 \%$. Tidak ada responden yang memiliki kriteria rendah. Jadi, siswa dinyatakan tuntas dalam belajar.

Tabel 4. Deskripsi Data tentang Prestasi Belajar Siswa

\begin{tabular}{cccc}
\hline Interval Nilai & Kriteria & Jumlah Responden & Persentase \\
\hline $100-83$ & Tinggi & 14 & $17 \%$ \\
$82-65$ & Sedang & 70 & $83 \%$ \\
$<65$ & Rendah & 0 & - \\
\hline Total & & 84 & $100 \%$ \\
\hline
\end{tabular}

Sumber: SMK Negeri 5 Madiun tahun ajaran 2015/2016

Uji validitas item kuesioner media pembelajaran dilakukan dengan menganalisis nilai korelasi antara skor item dengan skor total. Nilai tersebut kemudian dibandingkan dengan nilai $r$ tabel, $r$ tabel dicari pada signifikansi 0,05 dengan uji 2 sisi dan jumlah data dalam penelitian ini $(n)=84$, maka diperoleh $r$ tabel sebesar 0,213.Berdasarkan hasil analisis data diperoleh nilai korelasi untuk item 11 dan 12 kurang dari 0,213. Karena koefisien korelasi pada item 11 dan 12 nilai kurang dari 0,213, maka dapat disimpulkan bahwa item-item tersebut tidak berkorelasi signifikan dengan skor total (dinyatakan tidak valid) sehingga harus dikeluarkan atau diperbaiki. Sedangkan pada item-item lainnya nilainya lebih dari 0,213 dan dapat disimpulkan bahwa butir instrumen tersebut valid. 
Uji validitas item kuesioner keterampilan pengelolaan kelasdilakukan dengan menganalisis nilai korelasi antara skor item dengan skor total. Nilai tersebut kemudian dibandingkan dengan nilai $r$ tabel, $r$ tabel dicari pada signifikansi 0,05 dengan uji 2 sisi dan jumlah data dalam penelitian ini $(n)=84$, maka diperoleh $r$ tabel sebesar 0,213. Berdasarkan hasil analisis data diperoleh nilai korelasi untuk semua item lebih dari 0,213, maka dapat disimpulkan bahwa item-item tersebut berkorelasi signifikan dengan skor total. Jadi dapat disimpulkan bahwa butir instrumen tersebut valid.

Uji reliabilitas kuesioner tentang media pembelajaran menggunakan rumus Alpha Cronbach dan uji signifikan dilakukan pada taraf 0,05 artinya instrumen dikatakan reliabel jika nilai Alpha lebih besar dari r kritis Product Moment. Dari hasil analisis data diperoleh nilai Alpha sebesar 0,717 sedangkan nilai $r$ kritis (uji 2 sisi) pada signifikansi 0,05 dengan jumlah data $(\mathrm{n})=84$, diperoleh sebesar 0,213 . Karena nilainya lebih dari 0,213, maka dapat disimpulkan bahwa butir-butir instrumen penelitian tersebut reliabel.

Uji reliabilitas kuesioner tentang keterampilan pengelolaan kelas menggunakan rumus Alpha Cronbach dan uji signifikan dilakukan pada taraf 0,05 artinya instrumen dikatakan reliabel jika nilai Alpha lebih besar dari r kritis Product Moment. Hasil analisis data menunjukkan nilai Alpha sebesar 0,914 sedangkan nilai r kritis (uji 2 sisi) pada signifikansi 0,05 dengan jumlah data $(n)=84$, diperoleh sebesar 0,213 . Karena nilainya lebih dari 0,213, maka dapat disimpulkan bahwa butir-butir instrumen penelitian tersebut reliabel.

Langkah selanjutnya, peneliti melakukan uji asumsi klasik. Pada uji multikolinieritas, bila nilai VIF lebih besar daripada 10 maka dapat diindikasikan model tersebut memiliki gejala multikolinieritas (Setyadharma, 2011: 6). Tabel 5 menunjukkan nilai Variance Inflation Factor (VIF) kedua variabel yaitu media pembelajaran dan keterampilan pengelolaan kelas adalah 1,132 lebih kecil dari 10, sehingga dapat disimpulkan bahwa model tersebut tidak terjadi persoalan multikolinieritas.

Tabel 5. Hasil Uji Multikolinieritas

\begin{tabular}{ccc}
\hline Model & Variabel & VIF \\
\hline $\mathrm{X}_{1}$ & Media Pembelajaran & 1,132 \\
$\mathrm{X}_{2}$ & Keterampilan Pengelolan Kelas & 1,132 \\
\hline
\end{tabular}

Dalam penelitian ini, peneliti menggunakan Scatterplot untuk menguji apakah terjadi persoalan heteroskedastisitas. Menurut Singgih Santoso (2000:210), jika ada pola tertentu seperti titik-titik (point-point) yang ada membentuk suatu pola tertentu yang teratur (bergelombang, melebar kemudian menyempit), maka telah terjadi heteroskedastisitas. Jika tidak ada pola yang jelas serta titik-titik menyebar di atas dan di bawah angka nol pada sumbu Y, maka tidak terjadi heteroskedastisitas. Hasilnya menunjukkan pola scatterplot tidak membentuk pola tertentu yang teratur dan titiktitik pada scatterplot menyebar di atas dan di bawah angka nol pada sumbu $Y$, maka dapat disimpulkan bahwa model tersebut tidak terjadi masalah heteroskedastisitas.

Pengujian normalitas dalam penelitian ini menggunakan RasioSkewness dan Rasio Kurtosis untuk menguji apakah data yang diolah dalam keadaan normal. Menurut Santoso dalam Andryan Setyadharma(2011:2) bila rasio kurtosis dan skewness berada di antara -2 hingga +2 , maka distribusi data adalah normal. Tabel 6 menunjukkanrasio skewness adalah 0,355 kemudian dibagi dengan standar error 0,263, hasilnya adalah 1,349. Sedangkan rasio kurtosis adalah 0,273 kemudian dibagi dengan standar error 
0,520, hasilnya adalah 0,525. Jadi dapat disimpulkan bahwa distribusi data adalah normal.

Tabel 6. Hasil Uji Normalitas

\begin{tabular}{lcc}
\hline & Statistic & Standard Error \\
\hline Skewness & 0,355 & 0,263 \\
Kurtosis & 0,273 & 0,520 \\
\hline
\end{tabular}

Analisis data dalam penelitian ini menggunakan program SPSS for windows versi 17. Berdasarkan tabel 7, didapat persamaan:

$$
\begin{aligned}
& Y=a+b_{1} X_{1}+b_{2} X_{2} \\
& Y=52,506+0,338 X_{1}+0,311 X_{2}
\end{aligned}
$$

Persamaan regresi tersebut menunjukkan konstanta sebesar 52,506. Artinya jika media pembelajaran $\left(X_{1}\right)$ dan keterampilan pengelolaan kelas $\left(X_{2}\right)$ nilainya 0 , maka prestasi belajar $(\mathrm{Y})$ nilainya adalah 52,506.Koefisien regresi variabel media pembelajaran $\left(X_{1}\right)$ sebesar 0,338 artinya jika variabel independen lain nilainya tetap dan media pembelajaran mengalami kenaikan 1\%, maka prestasi belajar (Y) akan mengalami peningkatan sebesar 0,338. Koefisien bernilai positif artinya terjadi hubungan positif antara media pembelajaran dan prestasi belajar, semakin naik nilai media pembelajaran maka akan meningkatkan prestasi belajar.

Koefisien regresi variabel keterampilan pengelolaan kelas $\left(X_{2}\right)$ sebesar 0,311 artinya jika variabel independen lain nilainya tetap dan keterampilan pengelolaan kelas mengalami kenaikan 1\%, maka nilai prestasi belajar (Y) akan mengalami kenaikan sebesar 0,311. Koefisien bernilai positif artinya terjadi hubungan positif antara keterampilan pengelolaan kelas dan prestasi belajar, semakin naik nilai keterampilan pengelolaan kelas maka akan meningkatkan prestasi belajar.

Tabel 7. Hasil Uji Regresi Linear Berganda

\begin{tabular}{ccc}
\hline Variabel & Nilai $t$ & Signifikansi \\
\hline $\mathrm{X}_{1}$ & 3,376 & 0,001 \\
$\mathrm{X}_{2}$ & 5,802 & 0,000 \\
\hline
\end{tabular}

Uji hipotesis dilakukan dengan cara uji t. Uji hipotesis pertama dilakukan dengan melihat nilai t pada hasil analisis regresi Tabel 8. Berdasarkan tabel coefficients diperoleh thitung sebesar 3,376. Nilai tabeldicari pada signifikansi 0,05 dengan uji dua

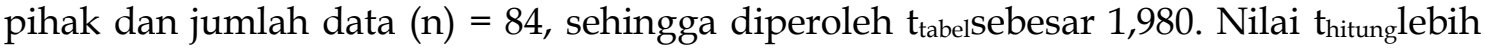
besar daripada $t_{\text {tabel }}(3,376>1,980)$, maka Ho ditolak. Artinya, ada pengaruh secara signifikan antara media pembelajaran dengan prestasi belajar. Jadi dari penelitian ini dapat disimpulkan bahwa secara parsial media pembelajaran berpengaruh terhadap prestasi belajar.

Uji hipotesis kedua dilakukan dengan melihat nilai $t$ pada hasil analisis regresi Tabel 7.Berdasarkan Tabel 7 diperoleh $t_{\text {hitung }}$ sebesar 5,802. Nilai $t_{\text {tabeldicari pada }}$ signifikansi 0,05 dengan uji dua pihak dan jumlah data $(n)=84$, sehingga diperoleh $t_{\text {tabel }}$ sebesar 1,980. Nilai $t_{\text {hitung }}$ lebih besar daripada $t_{\text {tabel }}(5,802>1,980)$, maka Ho ditolak. Artinya, ada pengaruh secara signifikan antara keterampilan pengelolaan kelas dengan prestasi belajar. Jadi dari penelitian ini dapat disimpulkan bahwa secara parsial keterampilan pengelolaan kelas berpengaruh terhadap prestasi belajar. 
Pengaruh simultan media pembelajaran dan keterampilan pengelolaan kelas dapat dilihat pada Tabel 8. Berdasarkan Tabel 8 diperoleh $F_{\text {hitung }}$ sebesar 33,060. Nilai

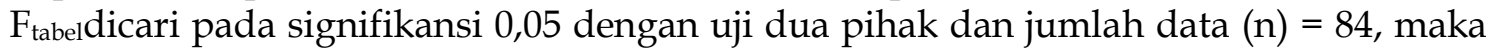
diperoleh $F_{\text {tabel }}$ sebesar 1,39. Nilai $F_{\text {hitung }}$ lebih besar daripada $F_{\text {tabel }}(33,060>1,39)$, maka Ho ditolak. Artinya, ada pengaruh secara signifikan antara media pembelajaran dan keterampilan pengelolaan kelas secara bersama-sama terhadap prestasi belajar. Jadi dalam penelitian ini dapat disimpulkan bahwa secara simultan media pembelajaran dan keterampilan pengelolaan kelas berpengaruh terhadap prestasi belajar.

Tabel 8. Hasil Uji F

\begin{tabular}{lcc}
\hline & Nilai F & Signifikansi \\
\hline $\mathrm{F}$ & 33,060 & 0,000 \\
\hline
\end{tabular}

\section{SIMPULAN}

Simpulan penelitian ini adalah media pembelajaran mempunyai pengaruh secara signifikan terhadap prestasi belajar. Kesimpulan kedua adalah keterampilan pengelolaan kelas mempunyai pengaruh secara signifikan terhadap prestasi belajar. Media pembelajaran dan keterampilan pengelolaan kelas sama-sama berpengaruh secara signifikan terhadap prestasi belajar. Keterbatasan dalam penelitian ini adalah hanya terdiri dari dua variabel independen yaitu media pembelajaran dan keterampilan pengelolaan kelas.Pada penelitian selanjutnya diharapkan bisa ditambah variabel interaksi siswa terhadap media pembelajaran.

Saran peneliti untuk sekolah yang dijadikan tempat penelitian adalah adanya perbaikan fasilitas belajar siswa seperti media pembelajaran agar siswa dapat termotivasi dalam mengikuti pelajaran dan dapat meningkatkan prestasi belajarnya. Sebaiknya guru menggunakan media pembelajaran yang sesuai dengan materi pelajaran agar siswa termotivasi dan antusias dalam mengikuti pelajarandemi tercapainya mutu pendidikan yang lebih baik.Guru harus dapat mengelola kelas dengan baik agar tercipta suasana kelas yang nyaman, kondusif dan mendukung bagi siswa agar tujuan pembelajaran dapat tercapai.

\section{DAFTAR PUSTAKA}

Belkaoui, A. R. (2000). Teori Akuntansi. Jakarta: Salemba Empat.

Baharuddin dan Esa N. W.. (2007). Teori Belajar \& Pembelajaran. Jogjakarta: Ar-Ruzz Media.

Burhan, B. (2005). Metodologi Penelitian Kuantitatif. Jakarta: Kencana Prenada Media Group.

Darwanto. (2007). Televisi Sebagai Media Pendidikan. Yogyakarta: Pustaka Pelajar.

Departemen Pendidikan Nasional Indonesia. (2003). Undang-Undang Republik Indonesia No. 20 Tahun 2003 Tentang Sistem Pendidikan Nasional. Jakarta.

Dimyati dan Mudjiono. (2002). Belajar dan Pembelajaran. Jakarta: Rineka Cipta.

Syukur, F. (2008). Teknologi Pendidikan. Semarang: Rasail Media Group.

Uno, H. B. (2007). Profesi Kependidikan. Jakarta: Bumi Aksara.

Tu'u, L. (2004). Peran Disiplin pada Perilaku dan Prestasi Siswa.Jakarta: Gramedia Widiasarana Indonesia.

Usman, M. U. (2006). Menjadi Guru Profesional. Bandung: Remaja Rosdakarya.

Mulyasa. (2005). Menjadi Guru Profesional. Bandung: Remaja Rosdakarya.

Sukmadinata, N. S. (2005). Landasan Psikologi Proses Pendidikan.Bandung: Remaja Rosdakarya. 


\section{ASSEIS JURNAL AKUNTANSI DAN PENDIDIKAN

Hamalik, O. (2004). Perencanaan Pengajaran Berdasarkan Pendekatan Sistem. Jakarta: Bumi Aksara.

Hamalik, O. (2004). Proses Belajar Mengajar. Jakarta: Bumi Aksara.

Fathurrohman, P. dan Sobry S. (2007). Strategi Belajar Mengajar. Bandung: Refika Aditama.

Raya. (2004). Upaya Meningkatkan Prestasi belajar Matematika dengan Media Pengajaran di SD Gondangsari IV Kelas IV. Universitas Negeri Yogyakarta.

Akbar, R. dan Hawadi. (2006). Akselerasi. Jakarta: PT. Grasindo.

Santoso, S. (2000). Buku Latihan SPSS Statistik Parametrik. Jakarta: Elex Media Komputindo.

Slameto. (2003). Belajar dan Faktor - Faktor yang Mempengaruhinya. Jakarta: Rineka Cipta.

Hadi, S. (2005). Pengelolaan Kelas. Surakarta: UNS Press.

Sugiyono. (2009). Metode Penelitian Kuantitatif Kualitatif dan R\&D. Bandung: Alfabeta.

Arikunto, S. (2008). Penelitian Tindakan Kelas. Jakarta: Bumi Aksara.

Sukardi. (2003). Metodologi Penelitian Pendidikan Kompetensi dan Praktiknya. Jakarta: Bumi Aksara.

Suwarna. (2006). Pengajaran Mikro. Yogyakarta: Tiara Wacana.

Suyatno. (2008). Perencanaan Pengajaran. Surakarta: UNS Press.

Djamarah, S. B. (2000). Guru dan Anak Didik dalam Interaksi Edukatif. Jakarta: Rineka Cipta.

Djamarah, S. B. (2002). Rahasia Sukses Belajar. Jakarta: Rineka Cipta.

Djamarah, S. B. dan Zain, A. (2002). Strategi Belajar Mengajar. Jakarta: Rineka Cipta.

Thoifuri. (2008). Menjadi Guru Inisiator. Semarang: Rasail Media Group.

Riyanto, Y. (2006). Metodologi Penelitian Pendidikan. Jakarta: Penerbit SIC.

Riyanto, Y. (2009). Paradigma Baru Pembelajaran. Jakarta: Kencana. 


\section{LAMPIRAN}

Hasil Uji Validitas dan Reliabilitas Media Pembelajaran $\left(X_{1}\right)$

Setelah Item yang Tidak Valid Dikeluarkan

Reliability Statistics

\begin{tabular}{|r|r|}
\hline $\begin{array}{c}\text { Cronbach's } \\
\text { Alpha }\end{array}$ & N of Items \\
\hline .787 & 10 \\
\hline
\end{tabular}

\begin{tabular}{|l|r|r|r|}
\hline \multicolumn{4}{|c|}{ Item Statistics } \\
\hline & Mean & Std. Deviation & N \\
\hline X1_1 & 4.38 & .820 & 84 \\
X1_2 & 4.19 & .784 & 84 \\
X1_3 & 3.95 & .835 & 84 \\
X1_4 & 4.06 & .797 & 84 \\
X1_5 & 3.54 & .924 & 84 \\
X1_6 & 3.42 & .921 & 84 \\
X1_7 & 3.67 & .948 & 84 \\
X1_8 & 4.14 & .794 & 84 \\
X1_9 & 3.65 & .898 & 84 \\
X1_10 & 3.40 & .971 & 84 \\
\hline
\end{tabular}

\section{Scale Statistics}

\begin{tabular}{|r|r|r|r|}
\hline Mean & Variance & Std. Deviation & N of Items \\
\hline 38.40 & 26.027 & 5.102 & 10 \\
\hline
\end{tabular}

Hasil Uji Validitas dan Reliabilitas Keterampilan Pengelolaan Kelas $\left(X_{2}\right)$

Reliability Statistics

\begin{tabular}{|r|r|}
\hline $\begin{array}{c}\text { Cronbach's } \\
\text { Alpha }\end{array}$ & N of Items \\
\hline .914 & 12 \\
\hline
\end{tabular}

Item-Total Statistics

\begin{tabular}{|l|r|r|r|r|}
\hline & $\begin{array}{c}\text { Scale Mean if } \\
\text { Item Deleted }\end{array}$ & $\begin{array}{c}\text { Scale Variance if } \\
\text { Item Deleted }\end{array}$ & $\begin{array}{c}\text { Cronbach's } \\
\text { Clpha if Item } \\
\text { Torrected Item- } \\
\text { Total Correlation }\end{array}$ \\
\hline X2_13 & 36.98 & 73.807 & .670 & .907 \\
X2_14 & 36.56 & 77.984 & .674 & .907 \\
X2_15 & 36.79 & 72.604 & .786 & .901 \\
X2_16 & 36.68 & 74.076 & .776 & .901 \\
X2_17 & 36.76 & 77.003 & .615 & .909 \\
X2_18 & 37.14 & 72.148 & .769 & .902 \\
X2_19 & 36.86 & 76.461 & .672 & .906 \\
X2_20 & 36.96 & 72.348 & .722 & .904 \\
X2_21 & 36.96 & 72.710 & .782 & .901 \\
X2_22 & 36.82 & 82.462 & .565 & .912 \\
X2_23 & 36.85 & 84.373 & .401 & .916 \\
X2_24 & 37.13 & 85.537 & .379 & .917 \\
\hline
\end{tabular}




\section{ASSETS}

Hasil Uji Asumsi Klasik

Multikolinieritas

\begin{tabular}{|c|c|c|c|c|c|c|c|}
\hline \multicolumn{8}{|c|}{ Coefficients $^{a}$} \\
\hline \multirow[b]{2}{*}{ Model } & \multicolumn{2}{|c|}{$\begin{array}{l}\text { Unstandardized } \\
\text { Coefficients }\end{array}$} & \multirow{2}{*}{$\begin{array}{c}\begin{array}{c}\text { Standardized } \\
\text { Coefficients }\end{array} \\
\text { Beta }\end{array}$} & \multirow[b]{2}{*}{$\mathrm{t}$} & \multirow[b]{2}{*}{ Sig. } & \multicolumn{2}{|c|}{$\begin{array}{l}\text { Collinearity } \\
\text { Statistics }\end{array}$} \\
\hline & B & Std. Error & & & & Tolerance & VIF \\
\hline 1 (Constant) & 52.506 & 3.740 & & 14.039 & .000 & & \\
\hline $\mathrm{X} 1$ & .338 & .100 & .296 & 3.376 & .001 & .884 & 1.132 \\
\hline $\mathrm{X} 2$ & .311 & .054 & .509 & 5.802 & .000 & .884 & 1.132 \\
\hline
\end{tabular}

Heteroskedastisitas

\section{Dependent Variable: $Y$}

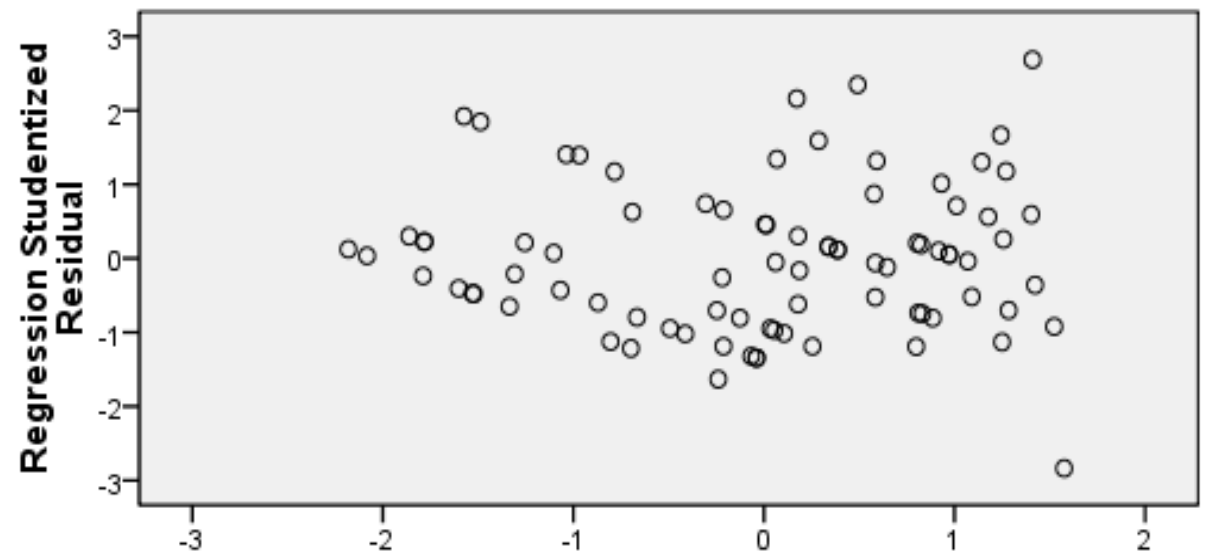

Regression Standardized Predicted Value

Normalitas

Descriptive Statistics

\begin{tabular}{|c|c|c|c|c|c|c|c|c|c|}
\hline & $\mathrm{N}$ & Min & Max & Mean & $\begin{array}{c}\text { Std. } \\
\text { Deviation }\end{array}$ & \multicolumn{2}{|c|}{ Skewness } & \multicolumn{2}{|c|}{ Kurtosis } \\
\hline & Statistic & Statistic & Statistic & $\begin{array}{c}\text { Statisti } \\
\text { C }\end{array}$ & Statistic & Statistic & Std. Error & Statistic & Std. Error \\
\hline $\begin{array}{l}\text { Unstandardized } \\
\text { Residual } \\
\text { Valid N (listwise) }\end{array}$ & $\begin{array}{l}84 \\
84\end{array}$ & $\begin{array}{r}- \\
12.1347 \\
0\end{array}$ & $\begin{array}{r}11.5140 \\
8\end{array}$ & $\begin{array}{r}.00000 \\
00\end{array}$ & 4.31815399 & .355 & .263 & .273 & .520 \\
\hline
\end{tabular}

Hasil Regresi Linier Ganda

Model Summary

\begin{tabular}{|l|r|r|r|r|}
\hline Model & $\mathrm{R}$ & R Square & \multicolumn{1}{|c|}{$\begin{array}{c}\text { Adjusted R } \\
\text { Square }\end{array}$} & $\begin{array}{l}\text { Std. Error of the } \\
\text { Estimate }\end{array}$ \\
\hline 1 & $.670^{\mathrm{a}}$ & .449 & .436 & 4.371 \\
\hline
\end{tabular}

a. Predictors: (Constant), X2, X1 
ARUMSARI, D.

PENGARUH MEDIA PEMBELAJARAN ...

ANOVA $^{\mathrm{D}}$

\begin{tabular}{|ll|r|r|r|r|r|}
\hline Model & & Sum of Squares & Df & Mean Square & F & Sig. \\
\hline 1 & Regression & 1263.332 & 2 & 631.666 & 33.060 & $.000^{\text {a }}$ \\
& Residual & 1547.656 & 81 & 19.107 & & \\
& Total & 2810.988 & 83 & & & \\
\end{tabular}

a. Predictors: (Constant), X2, X1

b. Dependent Variable: $Y$

\begin{tabular}{|c|c|c|c|c|c|c|}
\hline \multicolumn{7}{|c|}{ Coefficients $^{a}$} \\
\hline & & Unstandar & Coefficients & $\begin{array}{c}\text { Standardized } \\
\text { Coefficients }\end{array}$ & & \\
\hline \multicolumn{2}{|c|}{ Model } & B & Std. Error & Beta & $\mathrm{t}$ & Sig. \\
\hline \multirow[t]{3}{*}{1} & (Constant) & 52.506 & 3.740 & & 14.039 & .000 \\
\hline & $\mathrm{X} 1$ & .338 & .100 & .296 & 3.376 & .001 \\
\hline & $\mathrm{X} 2$ & .311 & .054 & .509 & 5.802 & .000 \\
\hline
\end{tabular}

a. Dependent Variable: Y

Hasil Analisis Uji t

\section{Coefficients $^{a}$}

\begin{tabular}{|c|c|c|c|c|c|c|}
\hline \multirow{2}{*}{\multicolumn{2}{|c|}{ Model }} & \multicolumn{2}{|c|}{ Unstandardized Coefficients } & \multirow{2}{*}{$\begin{array}{c}\begin{array}{c}\text { Standardized } \\
\text { Coefficients }\end{array} \\
\text { Beta }\end{array}$} & \multirow[b]{2}{*}{$\mathrm{t}$} & \multirow[b]{2}{*}{ Sig. } \\
\hline & & B & Std. Error & & & \\
\hline \multirow[t]{3}{*}{1} & (Constant) & 52.506 & 3.740 & & 14.039 & .000 \\
\hline & $\mathrm{X} 1$ & .338 & .100 & .296 & 3.376 & .001 \\
\hline & $\mathrm{X} 2$ & .311 & .054 & .509 & 5.802 & .000 \\
\hline
\end{tabular}

a. Dependent Variable: $Y$

Hasil Analisis uji F

ANOVA $^{\mathrm{D}}$

\begin{tabular}{|ll|r|r|r|r|r|}
\hline Model & & Sum of Squares & df & Mean Square & F & Sig. \\
\hline 1 & Regression & 1263.332 & 2 & 631.666 & 33.060 & $.000^{\mathrm{a}}$ \\
& Residual & 1547.656 & 81 & 19.107 & & \\
& Total & 2810.988 & 83 & & & \\
\end{tabular}

a. Predictors: (Constant), X2, X1

b. Dependent Variable: $Y$ 